\title{
Bezpieczne granie
}

DOI: 10.47050/65591777.254-282

Jeffrey Goldstein

Grami wideo zajmujemy się dla relaksu i rozrywki, ponieważ chcemy oderwać się od codziennego życia, ale także po to, żeby się uczyć, dbać o zdrowie lub prowadzić badania naukowe. Granie może przynieść potencjalne korzyści w czterech obszarach: poznania (percepcji), motywacji, emocji i funkcjonowania społecznego. Główne obawy dotyczące korzystania z gier wideo przez dzieci są związane z ich zawartością, z potencjalnym wpływem na zachowanie, z możliwością dostępu do nieodpowiednich treści. Wpływ gier na dzieci, zwłaszcza młodsze, w dużej mierze zależy od podejścia rodziców. Jeśli są oni zaniepokojeni ryzykiem, starają się chronić swoje dzieci, dlatego monitorują korzystanie z mediów, stosują ograniczenia i nadzorują. Gdy rodzice uważają, że media mogą być dobrym narzędziem edukacji lub rozrywki, częściej wspólnie korzystają z mediów z dziećmi lub rozmawiają z nimi o ich treściach. Rodzice powinni dawać przykład, korzystając z mediów w taki sposób, w jaki chcieliby, żeby robiły to ich dzieci.

\section{Słowa kluczowe:}

\section{gry wideo}

systemy klasyfikacji wiekowej PEGI i IARC

nadzór rodzicielski

mediacja rodzicielska

kontrola techniczna 


\section{Safe gaming}

DOI: 10.47050/65591777.254-282

Jeffrey Goldstein

Video games are used for relaxation, entertainment, and distraction, but also for education, health, and science. Playing video games has potential benefits in four areas: cognitive/perceptual, motivational, emotional, and social. The main concerns about children's video gaming are the content of games, the potential influence of games on behavior, about access to games that may be inappropriate for children. The influence that games have on children, especially younger children, largely depends on the parents own behavior. Parents who are concerned about risks most often try to protect their children by monitoring, applying restrictions on media use, and by supervising the child, whereas parents who feel that the media offer educational or entertainment opportunities more often co-use the media with their children or actively discuss the content. Parents should be good 'role models' for their children, using media in a manner that they want their children to follow.

\section{Keywords:}

video games

PEGI and IARC rating systems

parental guidance

parental mediation

technical controls 
Gry wideo są popularne w różnych grupach wiekowych i społecznych na całym świecie. Dzieci i dorośli, mężczyźni i kobiety regularnie z nich korzystają na konsolach, komputerach osobistych lub urządzeniach mobilnych, takich jak smartfony lub tablety.

Powody sięgania po gry wideo są zróżnicowane w zależności od wieku, umiejętności i zainteresowań. U nastolatków służą tym samym podstawowym celom, co inne media - umożliwiają poprawienie nastroju, zdobycie ciekawych doświadczeń i wzmocnienie relacji społecznych. Gry stanowią również wyzwanie i wymagają określonych umiejętności. Mogą silnie angażować, ale także zapewnić możliwości nawiązywania kontaktów społecznych w trakcie gry oraz po jej zakończeniu, zarówno w internecie, jak i podczas spotkań osobistych. Młodzi ludzie znajdują w nich inspirację, radość i ulgę.

Teoria użytkowania i gratyfikacji stanowi, że jednostki mają określone potrzeby, które sprawiają, że sięgają po media. Badania wskazują, że ludzie wybierają media (tradycyjne i wiązane z nowymi technologiami), aby zaspokoić co najmniej pięć ogólnych potrzeb:

$\rightarrow$ rozrywki,

$\rightarrow$ poszukiwania informacji,

$\rightarrow$ interakcji społecznej,

$\rightarrow$ zadowolenia emocjonalnego,

$\rightarrow$ zabicia czasu.

Nie każda gra nadaje się do osiągnięcia poszczególnych celów lub jest odpowiednia dla wszystkich graczy - dobra gra to taka, która jest dopasowana do zdolności, wieku, zainteresowań i potrzeb użytkowników.

\section{Argumenty za - pozytywne skutki gier wideo}

Grami wideo zajmujemy się dla relaksu i rozrywki albo z chęci oderwania się od codziennego życia, ale także po to, żeby się uczyć, dbać o zdrowie lub prowadzić badania naukowe. W XXI w. gry elektroniczne stały się skutecznymi narzędziami edukacyjnymi - udowodniono, że niektóre ich rodzaje wpływają na rozwój podstawowych zdolności wizualnych i myślowych. Rezultaty te są tak duże, że gry są wykorzystywane do praktycznych, rzeczywistych celów, na przykład szkolenia chirurgów czy rehabilitacji osób z deficytami percepcyjnymi lub poznawczymi. Chociaż przez wiele osób gry są postrzegane jako bezmyślna rozrywka, to ugruntowały one już swoją pozycję jako poważne i przydatne narzędzia. Wykorzystuje 
się w nich wiele technik stosowanych do propagowania skutecznego i możliwego w dowolnym miejscu procesu uczenia się. Chociaż niektórzy badacze wyrażają zaniepokojenie potencjalnymi negatywnymi skutkami gier, inni dostrzegają fakt, że szkolenia prowadzone z ich wykorzystaniem dają dobre rezultaty. „Współczesne gry wideo to coś więcej niż tylko rozrywka. Są one również bronią w walce ze zmniejszającymi się zdolnościami umysłowymi osób w podeszłym wieku. Upowszechniają nabywanie umiejętności zawodowych. I są wzorem tego, jak uczyć dzieci wykonywania złożonych i trudnych zadań oraz zdobywania umiejętności. Tak jak każda inna technologia, gry wideo nie są ze swej istoty ani dobre, ani złe. Charakter ich wpływu zależy od celu, w jakim wykorzystają je użytkownicy" (Eichenbaum, Bavelier, Green 2015, s. 67).

\section{Poznanie i postrzeganie}

Granie może przynieść potencjalne korzyści w czterech obszarach: poznania (percepcji), motywacji, emocji i funkcjonowania społecznego. Gry wideo mogą być skutecznymi narzędziami treningu mózgu, poprawiającymi skupienie wzroku, koncentrację, pamięć, poruszanie się i wielozadaniowość, przy jednoczesnym zwiększeniu szybkości i dokładności.

Niektóre gatunki gier są lepiej dostosowane do konkretnych rodzajów uczenia się - na przykład gry akcji, takie jak Grand Theft Auto, Call of Duty lub Battlefield, wymagają umiejętności wizualnych i poprawiają ich zakres. „Udowodniono, że gry akcji zwiększają wydajność behawioralną w odniesieniu do szerokiego zakresu zadań związanych z percepcją od tych wymagających efektywnej alokacji zasobów uwagi na całym obrazie, do tych, które wymagają zauważenia przelotnych bodźców. Osoby, które wcześniej nie miały do czynienia z grami wideo, po odbyciu szkolenia w zakresie gier akcji poprawiły zwoje umiejętności, szczególnie w zakresie umiejętności związanych z koncentracją uwagi" (Bediou i in. 2018). Zarówno krótkotrwałe, jak i długotrwałe korzystanie z gier może wpłynąć na poprawę zdolności poznawczych (percepcyjnych), które można wykorzystać w świecie rzeczywistym (Mayer 2014). Jedno z badań wykazało, że dwunastoletnie dzieci, które częściej korzystały z gier wideo, były bardziej kreatywne od rówieśników, którzy zajmowali się nimi w mniejszym stopniu (Jackson 2012).

Gry są wykorzystywane do nauki czytania, słownictwa i matematyki przez uczniów szkół podstawowych, a także w zakresie dba- 
nia o zdrowie przez młodzież (Kato 2010). Jedno z badań wykazało, że równie skutecznie, jak kursy akademickie, wpływały one na poprawę wyobraźni przestrzennej użytkowników, co ma przełożenie na proces nauki i rozwój kariery zawodowej w dziedzinach, w których liczą się tego rodzaju umiejętności, takich jak nauki ścisłe i techniczne, inżynieria i matematyka. Zauważono również, że im więcej nastolatkowie spędzali czasu na grach wymagających myślenia strategicznego, np. fabularnych, tym bardziej poprawiały się ich umiejętności rozwiązywania problemów i oceny w kolejnym roku szkolnym (Granic, Lobel, Engels 2014). Gry są najbardziej skuteczne, gdy już na etapie ich projektowania bierze się pod uwagę zasady uczenia się.

Gry wideo wykorzystują wiele zasad zaczerpniętych z procesu edukacyjnego, takich jak odpowiedzialność za podejmowanie decyzji, stawianie coraz trudniejszych wyzwań i angażowanie do eksperymentowanie z różnymi sposobami myślenia. Granie jest zajęciem „wielowymiarowym". Często zasadza się na interpretowaniu złożonych, trójwymiarowych obrazów, czytaniu tekstów zarówno na ekranie, jak i poza nim oraz przetwarzaniu informacji dźwiękowych. W grach komputerowych sukces przychodzi wraz z nabywaniem umiejętności i wiedzy. Młodzi ludzie muszą nauczyć się odczytywać subtelne niuanse, często opierając się na jedynie zdawkowych wskazówkach. Muszą również opanować zasady i etykietę komunikacji internetowej oraz szybko przemieszczać się między różnymi odmianami lub rejestrami języka (Goldstein, Buckingham, Brougère 2004). Gry mogą mieć wymiar edukacyjny, jeśli wymagają zdobywania odpowiednich informacji, ich organizowania i wykorzystywania do opracowywania strategii (Armstrong 2018).

„Badania sugerują, że chłopcy na ogół mają przewagę nad dziewczętami w odniesieniu do kilku typów umiejętności poznawczych, między innymi wyobrażania sobie, jak trójwymiarowe obiekty wyglądałyby z różnych perspektyw, i obliczania trajektorii lotu obiektu (takiego jak kula lub piłka nożna) w kierunku ruchomego celu. Ułatwia to chłopcom zaangażowanie się w gry z elementami strzelania, walki i sportu, które wymagają tych umiejętności - i może być kolejnym powodem [oprócz presji rówieśniczej] tego, że chłopcy chętniej niż dziewczęta wybierają te rodzaje gier" (Kutner, Olson 2008, s. 218). Należy jednak również zauważyć, że gry wideo to bardzo dobre narzędzia niwelowania różnic między płciami w zakresie wyobraźni przestrzennej (Dye, Green, Bavelier 2009). 
Rodzice i starsze rodzeństwo stanowią pomost na drodze rozwoju umysłowego dzieci, kiedy angażują się razem z nimi w gry i zachęcają ich do brania udziału w bardziej złożonych typach rozgrywki, a także do stosowania bardziej wyrafinowanego języka. Do opisania tego zjawiska Lev S. Vygotsky (1986) użył terminu "rusztowanie".

\section{Rozwój i funkcjonowanie mózgu}

Gry wideo mogą pozytywnie wpływać na mózg - korzystanie z nich powoduje rozwój obszarów mózgu odpowiedzialnych za orientację przestrzenną, zapamiętywanie i planowanie strategiczne, a także za umiejętności motoryczne.

Konkretne obszary mózgu można trenować. Agencja kosmiczna NASA opracowała gry wideo, które wykorzystują biologiczne sprzężenie zwrotne (biofeedback) do szkolenia czujności pilotów podczas długich misji i przygotowania ich do reakcji na sytuacje kryzysowe. Sygnały z czujników przymocowanych do głowy i ciała są przekazywane przez jednostkę przetwarzania sygnału do joysticka gry wideo. W miarę jak fale mózgowe gracza zbliżają się do optymalnego wzorca, czyli gracz staje się mniej zestresowany, posługiwanie się joystickiem staje się łatwiejsze (Mason i in. 2004). Technologia ta jest stosowana w powszechnie dostępnych konsolach Sony PlayStation i Microsoft Xbox w celu niwelowania objawów urazów mózgu, zespołu zaburzeń koncentracji uwagi i trudności w nauce. System umożliwia obsługę ogólnodostępnych gier (najlepsze są wyścigowe) za pomocą aktywności fal mózgowych. Im bardziej użytkownik jest skoncentrowany, im jego mózg szybciej pracuje, tym bardziej samochód przyspiesza i łatwiej jest prowadzić rozgrywkę. Stwierdzono, że dzięki temu urządzeniu dzieci z zespołem zaburzeń uwagi mogą wydłużyć czas koncentracji (Pope, Bogart 1996). Grami wideo można sterować przy użyciu wielu form biologicznego sprzężenia zwrotnego, w tym reakcji skórno-galwanicznej (galvanic skin response, GSR), tętna i temperatury ciała (Parente, Parente 2006).

Gra w Super Mario wpływa pozytywnie na komórki nerwowe w obszarach mózgu odpowiedzialnych za poruszanie się, zapamiętywanie, planowanie strategiczne i małą motorykę dłoni (czyli prawego hipokampu, prawej kory przedczołowej i móżdżku). Naukowcy z Instytutu Maksa Plancka w Berlinie poprosili mężczyzn i kobiety (średnio w wieku 24 lat) o granie w Super Mario 64 przez dwa miesiące po 30 minut dzien- 
nie. Grupa kontrolna nie grała w gry wideo. Objętość mózgu została zmierzona za pomocą rezonansu magnetycznego (MRI). W porównaniu z grupą kontrolną u graczy odnotowano wzrost substancji szarej, w której znajdują się ciała komórkowe komórek nerwowych mózgu. „Podczas gdy poprzednie badania wykazały różnice w strukturze mózgu graczy w gry wideo, obecne badanie może wykazać bezpośredni związek przyczynowo-skutkowy między grami wideo a wzrostem objętości mózgu. Dowodzi to, że określone obszary mózgu mogą być trenowane za pomocą gier" (Kühn, Gallinat 2014). Gry wideo mogą mieć działanie terapeutyczne na pacjentów z zaburzeniami psychicznymi, u których obszary mózgu są zmienione lub zmniejszone, na przykład w wypadku schizofrenii, stresu pourazowego lub chorób neurodegeneracyjnych (takich jak choroba Alzheimera).

Czy korzystanie z gier wideo ma wpływ na uczenie się i wyniki w nauce? W tej kwestii dowody nie są jednoznaczne. Wydaje się, że zależy to częściowo od tego, kiedy i w jakie gry grają nastolatki. W badaniu longitudinalnym z udziałem ponad 3,5 tys. niemieckich uczniów granie w gry do późna w nocy wiązało się z pogorszeniem ocen, chociaż nie było związku między graniem a samymi kompetencjami mierzonymi za pomocą testów umiejętności matematycznych i językowych (Gnambs i in. 2018). Uczniowie nadużywający gier chodzą spać później niż ci, którzy nie grają. Ich fizyczne i emocjonalne pobudzenie spowodowane intensywnymi sesjami gry może zmniejszyć czas snu w fazie REM i powodować, że ogólnie są oni mniej czujni i bardziej podatni na popełnianie błędów poznawczych (Vitelli 2018). Badacze twierdzą także (Gnambs i in. 2018), że "duża część histerii dotyczącej wpływu gier wideo na sukces szkolny prawdopodobnie jest nieuzasadniona. Chociaż wydaje się, że gry mają negatywny wpływ na oceny, to skala tego wpływu, mimo że znaczna, jest nadal bardzo mała".

Granie wymagające stosowania strategii wiąże się z lepszymi ocenami w szkole. Badanie przeprowadzone na próbie 1492 nastolatków w Stanach Zjednoczonych wykazało, że "granie w strategiczne gry wideo przyczynia się do wzrostu umiejętności rozwiązywania problemów, a to z kolei wiąże się z lepszymi wynikami w nauce. Nowatorskie odkrycie [tego wpływu] ma duże znaczenie, biorąc pod uwagę fakt, że miliony nastolatków grają w gry wideo każdego dnia. [...] Dzięki grom strategicznym, użytkownicy dowiadują się, że przed próbą rozwiązania problemu warto najpierw zebrać informacje i przemyśleć strategię. $\mathrm{Na}$ 
przykład w grze Splinter Cell (firmy Ubisoft) główny bohater jest agentem specjalnym, którego zadaniem jest skradanie się i ukrywanie przed wrogami podczas wykonywania misji. W przeciwieństwie do większości gier akcji i strzelanek, w których pędzi się w stronę wroga, strzelając z pistoletu, w Splinter Cell trzeba pozostać w ukryciu, poruszać się powoli i ostrożnie, prowadząc działania dywersyjne w celu odwrócenia uwagi wrogów. Na przykład zbliżając się do przeciwników, gracz musi zbadać sytuację, zebrać informacje o tym, w jakim obszarze się poruszają, i opracować plan tego, kiedy i w jaki sposób zaatakować, nie dając się zdemaskować. Strategia tego rodzaju często polega na oczekiwaniu na atak po tym, jak wróg przeniósł się w odległe miejsce, a następnie na ukrywaniu jego ciała. Biorąc pod uwagę, że ta forma rozwiązywania problemów - zdobywania informacji, rozważania różnych możliwości i formułowania strategii przed podjęciem działań - jest powtarzana na każdym poziomie gry, długotrwałe granie może zwiększyć umiejętności rozwiązywania problemów przez gracza" (Adachi, Willoughby 2013). W klasie gry symulacyjne umożliwiają wykonywanie czynności zbyt kosztownych lub zbyt niebezpiecznych, trudnych lub niepraktycznych do przeprowadzenia w rzeczywistych warunkach. Projektowanie gier i pisanie aplikacji jest częścią umiejętności informatycznych i w coraz większym stopniu jest uwzględniane w programie nauczania w szkole.

\section{Gry i zdrowie}

Sfera rozrywki wiąże się z kwestią zdrowia publicznego. Słuchanie muzyki, oglądanie filmów, korzystanie z gier wideo lub oglądanie wideo na YouTubie może wpłynąć na poprawę nastroju, wzmocnić przyjaźń i zwiększyć kompetencje. Gry rekreacyjne, które są łatwo dostępne i w których rozgrywka krótko trwa, takie jak Angry Birds lub Candy Crush, mogą poprawić nastrój gracza, pomóc mu się zrelaksować i zapomnieć o zmartwieniach. Nawet jeśli gry sprawiają tylko, że ludzie czują się szczęśliwsi, już samo w sobie jest korzystne dla zdrowia (Goldstein 2015).

Gry wideo są coraz częściej wykorzystywane w terapiach dzieci i dorosłych zmagających się z problemami zdrowotnymi w celu uzyskania informacji, propagowania aktywności fizycznej i przypominania, żeby przyjmowali leki. Gry ułatwiają odchudzanie i zdrowe odżywianie, a także leczenie chorób przewlekłych, takich jak cukrzyca i astma (Kato 2010; Lieberman 2009). Gry na telefony komórkowe i tablety są 
wykorzystywane w celu zwiększenia aktywności fizycznej, ściślejszego przestrzegania diety oraz podnoszenia świadomości na temat zdrowia i diety (na przykład: Byrne i in. 2012).

Gry wideo mogą uczyć pozytywnego reagowania na porażkę. Zdobywając umiejętność radzenia sobie z niepowodzeniami w grach, młodzi ludzie budują odporność emocjonalną, z której mogą korzystać w życiu codziennym (Granic, Lobel, Engels 2014).

Społeczność graczy online może być przyjaznym środowiskiem dla osób z zahamowaniami społecznymi, odczuwających niepokój lub nieśmiałych w sytuacjach społecznych. Dwa z podstawowych wyzwań okresu dorastania to poprawa umiejętności społecznych i komunikacji interpersonalnej. Urządzenia cyfrowe, takie jak telefony i komputery, zapewniają intymność i anonimowość, co pomaga takim osobom szybciej poczuć się pewnie i zdobyć różne umiejętności społeczne i komunikacyjne. Struktura gier online umożliwia nastolatkom testowanie granic społecznych i relacji na różne sposoby, co byłoby trudniejsze do realizacji w kontaktach bezpośrednich (Jansz 2005). Gry online mogą mieć korzystny wpływ społeczny na osoby nieśmiałe, pozwalając im przezwyciężyć trudności społeczne, nawiązywać przyjaźnie i zacieśniać istniejące relacje (Kowert i in. 2014; Trepte i in. 2012). World of Warcraft jest jedną z najpopularniejszych gier MMORPG (massively multiplayer online role-playing games). Jest to także społeczność i środowisko zachęcające do współpracy, komunikacji i nawiązywania przyjaźni. Gracze w sieci są znacznie mniej samotni i odczuwają w mniejszym stopniu niepokój społeczny niż w świecie rzeczywistym (Martončik, Lokša 2016).

Dzieci z zespołem zaburzeń koncentracji uwagi (attention deficit disorder, ADD) uwielbiają media, w tym telewizję, gry wideo i komputery. "Chłopcy z zaburzeniami częściej niż inni używali gier do radzenia sobie z uczuciem gniewu. Dwa razy więcej dziewcząt z ADD niż w całej populacji gra, aby nawiązać nowe znajomości. Takie sposoby korzystania z aplikacji wideo, pod warunkiem zachowania umiaru, mogą być uznane za zdrowe" (Kutner, Olson 2008, s. 134).

Szacuje się, że depresja dotyczy ponad 300 milionów ludzi na całym świecie. Chociaż odnotowano pewne sukcesy w leczeniu tej choroby za pomocą środków farmaceutycznych i terapii poznawczo-behawioralnej, to metody te są często kosztowne lub niedostępne. Badania potwierdzają skuteczność interwencji cyfrowych z wykorzystaniem gier w terapii depresji (Li i in. 2014; Russoniello, Fish, O'Brien 2013). 
Interaktywne gry ruchowe (exergames) to aplikacje wideo, które łączą rozgrywkę na ekranie z wysiłkiem fizycznym. Urządzenia cyfrowe z odpowiednimi czujnikami (takie jak Wii firmy Nintendo) umożliwiają śledzenie ruchów graczy i odwzorowanie ich w rozgrywce. Może to być wykorzystane w tańcu lub symulacji sportów, takich jak piłka nożna i tenis. Interaktywne gry ruchowe zastępują ćwiczenia fizyczne, gdy wyjście na zewnątrz nie jest możliwe, na przykład z powodu złej pogody lub w wypadku pacjentów w szpitalu (Peng i in. 2011). Jedno z badań wykazało, że tego rodzaju aplikacje wymagają znacznie więcej energii niż tradycyjne gry komputerowe, ale nie tyle samo, co rzeczywiste uprawianie danego sportu (Graves i in. 2010).

Jeśli interaktywne gry ruchowe sprawiają graczom przyjemność, prawdopodobnie osoby grające dłużej będą z nich korzystać, a to może stanowić namiastkę ćwiczeń. Oprócz wydatkowania energii gry te mogą mieć wpływ na zwiększenie pewności siebie, kontroli i zaangażowania. W badaniu młodych dorosłych w wieku 18-35 lat wykazano, że gry ruchowe, które sprawiają więcej przyjemności, powodują większe wydatki energetyczne (Lyons i in. 2014). Sportowe gry wideo, na przykład z serii FIFA (firmy Electronic Arts) i konsola Nintendo Wii nie zastępują prawdziwych sportów, ale stanowią ich dobre uzupełnienie.

Jeszcze większa aktywność jest konieczna w wypadku niektórych rozgrywek wykorzystujących rozszerzoną rzeczywistość, toczonych w świecie rzeczywistym za pomocą telefonu wyposażonego w system GPS. Tego rodzaju gry motywują ludzi do wyjścia na zewnątrz i mogą wymagać od nich, aby odwiedzali muzea, biblioteki, festiwale i parki. Ponieważ wiele osób jednocześnie gra w Pokémon GO, która wykorzystuje rozszerzoną rzeczywistość, gracze prowadzą bezpośrednią komunikację i nawiązują relacje (Stokes, Dols, Hill 2018).

Gry z elementami wirtualnej i rozszerzonej rzeczywistości wykorzystuje się coraz częściej w nauczaniu. Według jednego z przeglądów badań „wykorzystanie gier z elementami rozszerzonej rzeczywistości w środowiskach edukacyjnych wzmacnia aktywne i autentyczne uczenie się. Wszystkie badania, w których wykorzystano gry z elementami rozszerzonej rzeczywistości, wykazały pozytywny wpływ zarówno na zaangażowanie uczniów w naukę, jak i na ich uczestnictwo w zajęciach, a także na efekty uczenia się" (Koutromanos, Sofos, Avraamidou 2015). 


\section{Ryzyka i problemy: treści, dostęp, wpływ}

Główne obawy dotyczące korzystania z gier wideo przez dzieci związane są z treścią tych aplikacji, ich potencjalnym wpływem na zachowanie użytkowników, możliwością dostępu młodych ludzi do nieodpowiednich gier oraz z zagrożeniami, jakie stwarzają gry online przeznaczone dla wielu graczy. Rodzice wyrażają zaniepokojenie zawartymi w grach obrazami i treściami (przemoc, wulgaryzmy, stereotypy dotyczące płci, rasizm, pornografia, a także korzystanie z alkoholu, narkotyków i tytoniu), jak również hazardem i zakupami w aplikacjach. Ogólnie rzecz biorąc, rodzice martwią się, że ich dzieci poświęcają zbyt wiele czasu na granie i inne aktywności z wykorzystaniem urządzeń elektronicznych.

Od 2003 r. gry wideo dostępne w Europie są klasyfikowane w systemie PEGI (pegi.info/pl) w celu wskazania potencjalnych niepożądanych treści i zasugerowania wytycznych dotyczących wieku graczy. Od 2013 r. do celów oceniania aplikacji pobieranych online lub ze sklepu $z$ aplikacjami stosowana jest klasyfikacja IARC. Ponadto producenci urządzeń do gier i mediów interaktywnych wprowadzili zabezpieczenia, które umożliwiają rodzicom ograniczenie czasu ich użytkowania oraz filtrowanie niechcianych treści. To rodzice powinni decydować o tym, w co grają ich dzieci, i muszą być świadomi wpływu, jaki na nie mają gry (wskazówki dla rodziców dotyczące zarządzania graniem przez ich dzieci zawarto w części Zarzq̨dzanie grami za pomocą mediacji rodzicielskiej, s. 277).

\section{Gry wideo zawierające przemoc}

Najbardziej kontrowersyjnym aspektem gier wideo są treści zawierające przemoc. Wojna, strzelanki i sztuki walki to tematy wielu gier, zwłaszcza tych sklasyfikowanych jako PEGI-16 i PEGI-18, ale nawet aplikacje potencjalnie odpowiednie dla graczy w wieku 7-12 lat mogą zawierać elementy przemocy. Gry wideo zawierające tego rodzaju materiały to cyfrowe wersje komiksów, gotyckich powieści grozy i innych form groteskowej przemocy, traktowanej jako element rozrywki. Nie można zapominać, że gry i zabawy zawierające elementy przemocy zawsze były popularne, zwłaszcza wśród chłopców.

Wielu chłopców korzysta z gier zawierających elementy przemocy $w$ celu radzenia sobie $z$ gniewem, frustracją lub stresem. Młodzież używa tych aplikacji do wyzwolenia emocji - szczególnie chłopcy, dla których jest to sposób na zrelaksowanie się, zapomnienie o problemach 
i oswojenie uczucia gniewu. Gry mogą również pomóc młodym ludziom zrozumieć emocje i radzić sobie z nimi (Jansz 2005; Villani i in. 2018).

„Mocny związek między przemocą w grach wideo a przemocą w świecie rzeczywistym oraz wniosek, że gry prowadzą do izolacji społecznej i osłabienia umiejętności interpersonalnych, wynika ze złych lub z nieistotnych badań, błędnego myślenia i bezpodstawnych, uproszczonych analiz" - piszą Lawrence Kutner i Cheryl Olson w książce Grand Theft Childhood (2008, s. 8).

Niedawno przeprowadzone analizy na dużą skalę nie wykazują, że gry zawierające elementy przemocy mają bezpośrednie przełożenie na przemoc w życiu codziennym. W badaniu z 2018 r. sprawdzano skutki długotrwałego korzystania z tego rodzaju aplikacji. Jego realizatorzy wykorzystali dużą liczbę testów (w tym kwestionariuszy) do behawioralnych pomiarów między innymi poziomu agresji, postaw seksistowskich, empatii i kompetencji interpersonalnych, poszukiwania wrażeń, znudzenia i skłonności do podejmowania ryzyka, zdrowia psychicznego (depresja, lęk), a także funkcji poznawczych, przed rozpoczęciem grania i po dwóch miesiącach grania. W tym czasie uczestnicy badania codziennie grali w aplikację z elementami przemocy (Grand Theft Auto V), w aplikację niezawierającą przemocy (The Sims 3) lub w ogóle nie grali. Nie zaobserwowano żadnych istotnych zmian wśród przedstawicieli wszystkich grup. „Wyniki te dostarczają mocnych dowodów przeciwko często podawanym argumentom, że gry wideo z elementami przemocy mają negatywny wpływ na dorosłych graczy. Będą w związku $z$ tym pomocne $\mathrm{w}$ przedstawieniu bardziej realistycznego, naukowego spojrzenia na oddziaływanie gier wideo z elementami przemocy na użytkowników" (Kühn i in. 2018).

Patrick M. Markey, Charlotte N. Markey i Juliana E. French (2014) zbadali związki między przestępstwami z użyciem przemocy (zabójstwa i napaści), sprzedażą gier wideo, wyszukiwaniem w internecie poradników dotyczących gier zawierających przemoc oraz datami premiery popularnych aplikacji tego rodzaju. Realizatorzy badania nie znaleźli dowodów na potwierdzenie powtarzanej często tezy, że gry mają związek z agresywnymi atakami i zabójstwami w Stanach Zjednoczonych lub że mają przełożenie na przemoc w rzeczywistym świecie. Zaskakujące było to, że wiele wyników wskazywało na obniżenie liczby podobnych przestępstw wśród graczy. 
Po zbadaniu wpływu gier wideo na młodzież amerykańską psychologowie Lawrence Kutner i Cheryl Olson z Uniwersytetu Harvarda stwierdzili, że "być może najważniejszym wnioskiem wyciągniętym z naszych badań jest ten, że większość rodziców nie powinna się martwić o to, że gry wideo zawierające przemoc lub innego rodzaju aplikacje dla dorosłych mają duży wpływ na zachowania ich dzieci lub ich świat wartości. Przeprowadzając wywiady z nastolatkami, którzy grali w takie gry, wielokrotnie byliśmy pod wrażeniem tego, jak dobrze przyswoili oni sobie podstawowe wartości wyznawane przez rodziców. Zdawali oni sobie sprawę z tego, że gry wideo, choć czasem szokujące, są formą rozrywki i - podobnie jak kryminały lub komiksy z elementami grozy, filmy gangsterskie i powieści sensacyjne z których korzystały wcześniejsze pokolenia - nie przynależą do rzeczywistego świata" (Kutner, Olson 2008, s. 210).

\section{Czas spędzony przed ekranem: nadużywanie gier}

Rodzice i nauczyciele często skarżą się na to, że dzieci spędzają zbyt wiele czasu przed ekranem. Z pewnością nadużywanie gier przez nastolatków może być oznaką innych problemów, takich jak pogorszenie się lub zerwanie więzi rodzinnych czy przyjaźni, problemy emocjonalne albo kłopoty z nauką. Nadużywanie gier występuje wtedy, gdy wpływa na edukację lub pracę, zmniejsza ilość snu lub wypiera inne pożądane czynności, takie jak bezpośrednie interakcje z kolegami, relacje rodzinne albo uprawianie sportów.

Terminy "uzależnienie od gier wideo" lub „zaburzenia związane z grami internetowymi" są kontrowersyjne. Kryteria diagnostyczne, odpowiednie objawy i metody pomiarów nie zostały jeszcze jednoznacznie określone. Nie ma pewności, czy zaburzenia tego rodzaju powinny być traktowane odrębnie czy w powiązaniu z innymi chorobami (Aarseth i in. 2017). Obecne podejścia do rozumienia "uzależnienia od gier" opierają się na badaniach nad "tradycyjnymi" uzależnieniami od substancji i niekoniecznie przekładają się na dziedzinę gier wideo (Bean i in. 2017).

W dokonanym w 2018 r. przeglądzie zagadnień dotyczących gier stwierdzono, że „niezależnie od tego, w jaki sposób badacze i pracownicy służby zdrowia oceniają charakter zaburzeń związanych z grami wideo, niewielu graczy doświadcza negatywnych skutków korzystania z nich, jedynie niewielki odsetek tej grupy można traktować jak osoby uzależnione" (Gorman, Gentile, Green 2018). 
Istnieją dwie główne oznaki, które sygnalizują niezdrowe podejście dziecka do technologii. Jedna ma charakter behawioralny, druga - emocjonalny. Z punktu widzenia behawioralnego ważne jest rozpoznanie, kiedy urządzenia elektroniczne pochłaniają na tyle dużo czasu, że brakuje go już na zabawę offline, ćwiczenia fizyczne i kontakt z innymi ludźmi. Biorąc pod uwagę sferę emocjonalną, niezbędne jest rozpoznanie, kiedy dzieci doświadczają negatywnych emocji po zakończeniu gry, ponieważ czują się zastraszane, poddawane ostracyzmowi lub nieszczęśliwe w wyniku interakcji online. Do takich sytuacji może dojść po wizycie na portalach społecznościowych, wymianie wiadomości tekstowych lub udziale w grze fabularnej dla wielu graczy. Jeśli granie staje się problematyczne, porozmawiaj z dzieckiem o ustaleniu ograniczeń w tym zakresie.

\section{Ryzyka związane z grami online}

W grze online może brać jednocześnie udział ogromna liczba uczestników. Liczne gry wieloosobowe (massively multiplayer online games, MMO) są rozgrywane przez wirtualne społeczności, co może narazić graczy na ryzyko związane z interakcją w czasie rzeczywistym z nieznanymi osobami. Młodzi użytkownicy internetu nie zawsze są świadomi potencjalnych zagrożeń związanych z aktywnością w sieci. Do takich ryzyk zalicza się:

$\rightarrow$ Treści tworzone przez użytkowników w grze, które mogą być nieodpowiednie dla młodych graczy i niedopasowane do klasyfikacji wiekowej danej gry.

$\rightarrow$ Cyberprzemoc - niektórzy gracze zachowują się w sposób nieprzystający młodym ludziom, na przykład stosują niewłaściwy lub obraźliwy język, zastraszają innych (dzięki możliwości komunikacji tekstowej, głosowej lub wideo), zachowują się nie fair (oszukują) lub są agresywni wobec innych.

$\rightarrow$ Naruszenie prywatności - gry online mogą zachęcać użytkowników, w tym dzieci, do nawiązywania relacji, a to wiąże się z ryzykiem dzielenia się danymi osobowymi lub spotykania się z nieznanymi osobami w świecie realnym.

$\rightarrow$ Linki do stron internetowych z treściami nieodpowiednimi dla młodych ludzi. 
Dzieci muszą nauczyć się chronić się przed zagrożeniami internetowymi, w tym cyberprzemocą, nagabywaniem seksualnym oraz ryzykownymi zachowaniami seksualnymi w sieci (Baumgartner, Valkenburg, Peter 2010). Aby zminimalizować te zagrożenia, gracze i ich rodzice powinni o nich rozmawiać i wspólnie zdecydować, jakie środki ochrony zastosować. Wiąże się to z podejściem obejmującym ocenę treści gier, kontrolę dostępu do gier i naukę odpowiedzialnego grania.

\section{Bezpieczne granie}

Obawy rodziców i nauczycieli dotyczące gier wideo koncentrują się na ich treściach i dostępie do nich oraz na wpływie gier na dzieci. Tematy, obrazy i dźwięki w grach wideo mogą być nieodpowiednie dla młodszych graczy. Wielu rodziców martwi się występującymi w grach przemocą, stereotypami związanymi z płcią i innymi, które mogą być w nich przedstawiane, pojawiającymi się wulgaryzmami lub prezentacją narkotyków, alkoholu i tytoniu. Te i inne potencjalnie problematyczne treści gier wideo są opisane przez krajowe i międzynarodowe systemy klasyfikacji mediów. Klasyfikacje PEGI i IARC w wypadku gier wideo dotyczą treści, opisują tematy i elementy aplikacji oraz określają zalecenia dotyczące minimalnego wieku graczy. Jednocześnie są wprowadzane modyfikacje techniczne ograniczające dostęp do gier i innych mediów. Każde urządzenie zawiera mechanizmy kontroli rodzicielskiej, które można ustawić w taki sposób, aby ograniczyć dostęp do niektórych gier na podstawie ich klasyfikacji wiekowej PEGl oraz określić czas rozgrywki. Wpływ gier na dzieci, zwłaszcza młodsze, w dużej mierze zależy od zachowania rodziców posiadających wiedzę w tym zakresie. Rodzice powinni być dobrymi wzorami do naśladowania dla swoich dzieci i powinni korzystać z mediów w taki sposób, w jaki chcieliby, żeby robiły to ich dzieci. Są oni pierwszymi i najważniejszymi nauczycielami edukacji medialnej. Poniżej zaprezentowano wskazówki dla rodziców dotyczące możliwie optymalnego korzystania z gier przez ich dzieci.

\section{Systemy oceny treści: klasyfikacja na podstawie minimalnego wieku graczy i opisy zawartości - PEGI i IARC}

Dorośli i dzieci regularnie korzystają z gier na konsolach, smartfonach, tabletach lub komputerach. Większość gier jest odpowiednia dla graczy w każdym wieku, ale niektóre z nich są przeznaczone dla starszych użytkowników. W związku z tym w Europie aplikacje są klasyfikowane 
na podstawie zalecanego wieku graczy i opisu zawartości, dzięki czemu możliwe jest informowanie konsumentów i zapobieganie narażeniu dzieci na kontakt z nieodpowiednimi materiałami. Klasyfikacja wiekowa stanowi wskazówkę dla użytkowników, szczególnie dla rodziców, pomocną przy podejmowaniu decyzji o zakupie danego produktu dla dziecka.

\section{PEGI}

Ogólnoeuropejski system klasyfikacji gier PEGI (Pan-European Game Information) służy oznaczaniu wiekowemu aplikacji wideo. Celem PEGI jest „edukowanie konsumentów, szczególnie zaś ochrona nieletnich przed narażeniem ich na potencjalnie nieodpowiednie treści gier. PEGI zapewnia rodzicom i opiekunom szczegółowe informacje umożliwiające dokonywanie świadomych wyborów przy zakupie gier dla dzieci". Klasyfikacja określa minimalny zalecany wiek graczy, a piktogramy przedstawiają treść gry (ilustracje 1-10). Klasyfikacja PEGI jest stosowana w 38 krajach. Od 2013 r., IARC (International Age Rating Coalition) wydaje oceny aplikacji i materiałów do pobrania (www.globalratings.com).

W Polsce grami wideo zajmuje się Stowarzyszenie Producentów i Dystrybutorów Oprogramowania Rozrywkowego - SPIDOR, które powstało w 2008 r. Prowadzi ono działalność edukacyjną, publikuje informacje o grach na swojej stronie internetowej oraz wspiera branżę gier wideo w Polsce (www.spidor.pl).

Ilustracja 1. Przegląd klasyfikacji wiekowej PEGI ${ }^{1}$

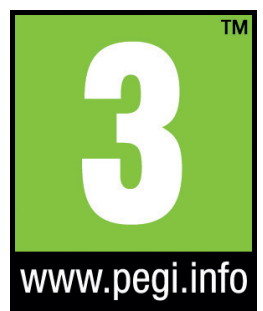

Gra odpowiednia dla wszystkich grup wiekowych. Pewna ilość przemocy (o komicznym lub dziecięcym charakterze). Bohaterowie są wytworem fantazji. Gra nie zawiera nieodpowiednich treści. 

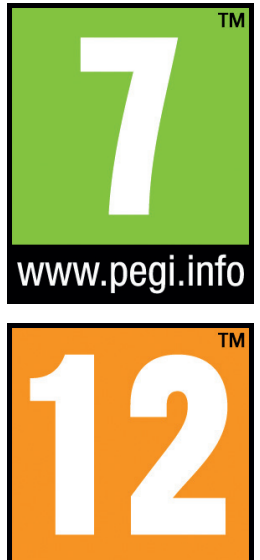

www.pegi.info
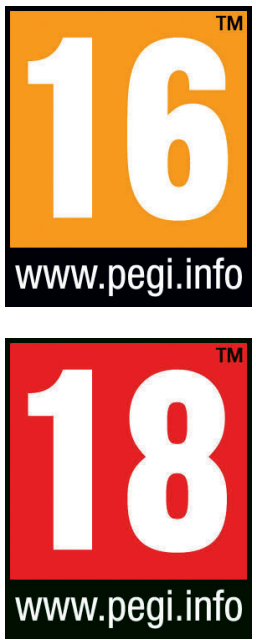

Przemoc przedstawiona lub sugerowana nierealistycznie. Obrazy animowane i zabawne. Sceny walki odpowiednie dla małych dzieci.

Gra pokazująca przemoc o realistycznym charakterze, skierowaną przeciw postaciom fantastycznym lub nierealistyczną przemoc wobec postaci przypominających ludzi bądź zwierzęta. Ewentualne wulgaryzmy muszą mieć łagodny charakter. Dopuszczalne są nagość i strach.

Przemoc wyglądająca tak, jak w rzeczywistości, skierowana przeciw postaciom ludzkim. Prezentacja przemocy w sporcie i widok krwi. Wulgaryzmy, sceny pokazujące używanie narkotyków oraz sceny popełniania przestępstw.

Gry przedstawiające daleko posuniętą przemoc lub przemoc skierowaną przeciw bezbronnym postaciom ludzkim. Gloryfikowanie zażywania narkotyków i ostrzejsze sceny seksualne.

System PEGI uwzględnia to, czy gra jest odpowiednia dla użytkowników w określonym wieku, ale nie jej poziom trudności. Zgodnie z klasyfikacją PEGI 3 gra nie będzie zawierać żadnych nieodpowiednich treści, ale czasami może być zbyt trudna do opanowania przez młodsze dzieci. Występują również gry sklasyfikowane jako PEGI 18, które są bardzo łatwe, ale zawierają elementy nieodpowiednie dla młodszych użytkowników. 


\section{Opisy treści PEGI}

W ramach systemu klasyfikacji PEGI stosuje się osiem piktogramów ilustrujących treści gier.

PRZEMOC

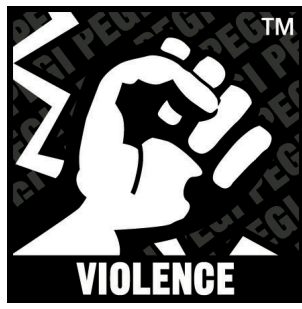

WULGARNY JĘZYK

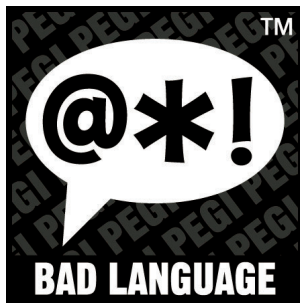

STRACH

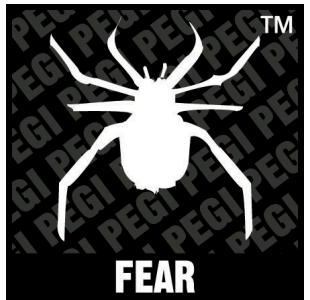

HAZARD

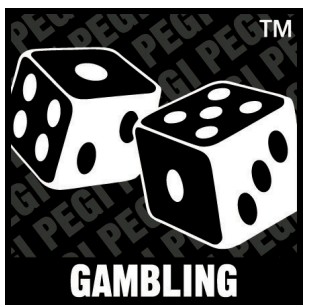

Gra zawiera elementy przemocy. W grach oznaczonych jako PEGI 7 mogą występować tylko nierealistyczne lub mało szczegółowe obrazy przemocy. Gry ze znakiem PEGl 12 mogą przedstawiać przemoc w środowisku fantasy lub nierealistyczne obrazy przemocy wobec postaci o ludzkim wyglądzie, podczas gdy gry sklasyfikowane jako PEGI 16 lub PEGI 18 zawierają zdecydowanie bardziej realistyczne obrazy przemocy.

Gra zawiera wulgaryzmy. Ten opis można znaleźć w grach z klasyfikacją wiekową PEGI 12 (łagodne wulgaryzmy), PEGI 16 (na przykład niecenzuralne słowa związane z seksem lub bluźnierstwa) lub PEGI 18 (na przykład odwołania do seksu lub bluźnierstwa).

Opis może pojawić się na grach z klasyfikacją wiekową PEGI 7, jeśli zawierają one obrazy lub dźwięki, które mogą przestraszyć albo przerazić małe dzieci, lub na grach PEGI 12 z przerażającymi dźwiękami albo efektami budzącymi grozę (ale bez zawartości przemocy).

Gra zawiera elementy, które zachęcają do hazardu lub uczą jego zasad. Symulacje gier hazardowych odnoszą się do gier losowych, które zazwyczaj można znaleźć w kasynach lub salach gier. Aplikacje z tego rodzaju treściami noszą znaki PEGI 12, PEGI 16 lub PEGI 18. 
SEKS

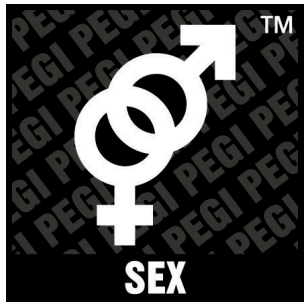

NARKOTYKI

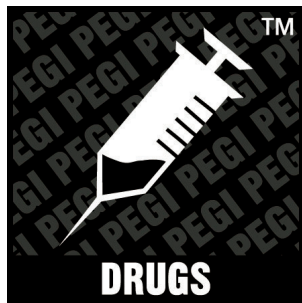

DYSKRYMINACJA

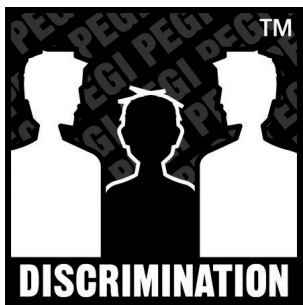

ZAKUPY W GRZE

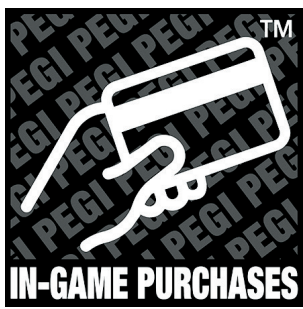

Ten opis może towarzyszyć znakowi PEGI 12, jeśli gra zawiera pozy lub podteksty seksualne, PEGI 16, jeśli występują nagość z podtekstem erotycznym lub stosunek seksualny bez widocznych narządów płciowych, albo ocenie PEGI 18, jeśli w grze przedstawiona jest aktywność seksualna. Sceny nagości bez kontekstu seksualnego nie wymagają specjalnego ratingu wiekowego $i$ ten opis nie byłby konieczny.

Gra odnosi się do zażywania narkotyków, picia alkoholu lub palenia tytoniu albo pokazuje takie czynności. Aplikacje z tego rodzaju opisem treści zawsze są klasyfikowane jako PEGI 16 lub PEGI 18.

Gra zawiera stereotypy o charakterze etnicznym, religijnym, płciowym, nacjonalistycznym lub inne, które mogą zachęcać do nienawiści. Takie treści zawsze wiążą się z klasyfikacją wiekową PEGI 18 (i mogą naruszać krajowe przepisy prawa karnego).

W 2018 r. PEGI dodało nowy opis treści: zakupy w ramach gry (in-game purchases), informujący rodziców o możliwości wydawania pieniędzy podczas rozgrywki. Nowe wersje, treści i funkcje danej gry lub aplikacji są regularnie oferowane użytkownikom. Jeśli takie zakupy są dokonywane w trakcie rozgrywki, są nazywane zakupami w ramach gry (lub zakupami w ramach aplikacji na urządzenia przenośne), chociaż mogą również obejmować osobne pozycje dostępne w zewnętrznych sklepach internetowych. W niektórych wypadkach gracz może dokonać zakupu (nowego elementu lub nowej wersji) za prawdziwe pieniądze, a w innych może zakupić wirtualną walutę w grze za prawdziwe pieniądze, możliwą do zamiany na konkretne elementy podczas gry.

Przykłady zakupów $w$ ramach gry to między innymi:

$\rightarrow$ Monety, punkty, diamenty itp., czyli przykładowa waluta w grze, która może być wymieniana na nową zawartość, nowe funkcje lub nowe wersje aplikacji.

$\rightarrow$ Poziomy/mapy - dodatkowe poziomy lub obszary wewnątrz świata gry mogą być odblokowane za pomocą zakupów online. 
$\rightarrow$ Postacie - można zakupić nowe postacie z różnymi zestawami umiejętności w celu ponownego, odmiennego ukończenia gry.

$\rightarrow$ Broń/narzędzia - gra oferuje standardowy zestaw wyposażenia, narzędzi lub broni umożliwiających pokonywanie kolejnych poziomów, a oprócz tego dostępne są przedmioty o zwiększonej funkcjonalności, ułatwiające ukończenie niektórych etapów.

$\rightarrow$ "Skórki" - przedmioty, które mogą być noszone przez awatara lub dodawane do wirtualnego wyposażenia (na przykład samochodów, rowerów lub domów). Przykładami mogą być: odzież, tatuaże, biżuteria, kalkomania, tablice rejestracyjne.

$\rightarrow$ Z wielu gier można korzystać bez dokonywania dodatkowych zakupów. Podobnie jak w wypadku każdego zakupu online, ważne jest, aby rodzice wiedzieli, jak kontrolować zakupy w grze za pośrednictwem platform i urządzeń używanych przez ich dzieci. Platformy i sklepy internetowe oferują narzędzia umożliwiające konsumentom podejmowanie świadomych decyzji, w tym w imieniu dzieci, oraz ustanowienie kontroli ustawień związanych z zakupami cyfrowymi, dostępem do internetu, interakcjami online i innymi funkcjonalnościami.

Według badania z maja 2018 r. w wielu krajach większość rodziców ustaliła z dziećmi zasady wydawania pieniędzy w związku z grami wideo. Simon Little, dyrektor zarządzający PEGl, podkreśla znaczenie zaangażowania rodziców w ten obszar aktywności. „Wszyscy rodzice powinni prowadzić rozmowy z dziećmi na temat gier. Zapewni im to warunki niezbędne do stworzenia takiego środowiska, w którym obie strony będą się dobrze czuć".

\section{W jaki sposób gry są klasyfikowane?}

Wiele gier komputerowych i na konsole (Microsoft Xbox, Sony PlayStation, Nintendo) jest wydawanych w wersjach pudełkowych i sprzedawanych w sklepach. Żeby mieć pewność, że gry są właściwie sklasyfikowane pod względem wieku, przestrzegana jest rygorystyczna procedura:

1. Przed publikacją wydawcy gry wypełniają formularz oceny treści w odniesieniu do każdej wersji produktu. W kwestionariuszu odpowiadają na pytania o zawartość gry, biorąc pod uwa- 
gę możliwość występowania przemocy, seksu, wulgaryzmów i innych treści audiowizualnych, które mogą być nieodpowiednie dla młodszych graczy.

2. Na podstawie informacji wydawcy system online automatycznie określa tymczasową klasyfikację wiekową oraz opisy treści.

3. Administrator PEGI otrzymuje produkt od wydawcy i dokładnie weryfikuje wstępną klasyfikację wiekową.

4. Jeżeli zawartość gry odpowiada wstępnej klasyfikacji, PEGI udziela wydawcy licencji na korzystanie z ikony oceny wiekowej i odpowiednich opisów treści.

5. Wydawca zostaje upoważniony do umieszczania logo klasyfikacji wiekowej i opisów treści na opakowaniu produktu lub w punkcie sprzedaży, zgodnie z kodeksem postępowania PEGI.

\section{IARC}

Codziennie pojawiają się setki nowych gier i aplikacji na smartfony, tablety, komputery i konsole. IARC (International Age Rating Coalition), międzynarodowa koalicja organów ratingowych z Europy (PEGI i USK, www.usk.de/en/classification/age-rating-symbols), Ameryki Północnej (ESRB, www.esrb.org), Brazylii (ClassInd, culturadigital.br/classind) i Australii (ACB, www.classification.gov.au/Pages/Home.aspx), ma na celu dokonanie klasyfikacji wiekowych i opisów zawartości gier wideo, materiałów do pobrania i aplikacji. Zamiast administrować własnymi systemami ratingowymi, sklepy i platformy korzystają z uznanych metod oceny, aby spełniać wymagania opisu treści obowiązujących w każdym kraju. Konsumenci otrzymują spójny zestaw ogólnie przyjętych ocen, spełniających wymogi lokalne dotyczące treści gier i minimalnego wieku graczy.

\section{Jak działa IARC?}

1. Wydawca przesyła grę lub aplikację w celu przeprowadzenia oceny nowej gry cyfrowej lub aplikacji. Część procedury składania wniosków obejmuje wypełnienie przez wydawcę kwestionariusza 
IARC, z pytaniami dotyczącymi zawartości produktu i elementów interaktywnych. Kwestionariusz uwzględnia kryteria klasyfikacji podmiotów doradczych (w tym PEGI, USK, ESRB).

2. Po wypełnieniu kwestionariusza wydawca natychmiast otrzymuje licencję zawierającą klasyfikację wiekową komitetów doradczych. Proces klasyfikacji jest nieodpłatny. W momencie publikacji gry lub aplikacji podawane są informacje o odpowiedniej kategorii wiekowej.

3. Administratorzy z komitetów doradczych IARC weryfikują wszystkie klasyfikacje, aby się upewnić, że kryteria wiekowe są właściwie stosowane. W wypadku wystąpienia błędu można dokonać zmiany klasyfikacji wiekowej.

Aplikacje są często portalami dla treści, które są generowane przez użytkowników. Sklepy internetowe (na przykład sklep Amazon), komercyjne media strumieniowe (na przykład Netflix), aplikacje społecznościowe (na przykład Facebook) oraz portale z treściami generowanymi przez użytkowników (na przykład YouTube) zawierają różnego rodzaju treści. IARC nie ma możliwości określenia przed wydaniem aplikacji, jaki rodzaj nieodpowiednich treści może ona zawierać. W wypadku aplikacji innych niż gry pojawiają się zalecenia dotyczące nadzorowania przez rodziców treści, do jakich dostęp mają ich dzieci. Nowa ikona ostrzega, że przy pobieraniu danej aplikacji zalecany jest nadzór rodzicielski.

WSKAZANY NADZÓR RODZICIELSKI

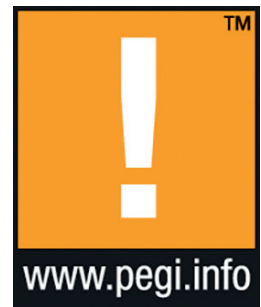




\section{Ograniczanie dostępu za pomocą środków technicznych:}

\section{kontrola rodzicielska konsol i urządzeń do gier}

Wszystkie konsole do gier, urządzenia przenośne oraz systemy operacyjne do komputerów PC i Mac są wyposażone w systemy kontroli rodzicielskiej, pozwalające rodzicom chronić prywatność swoich dzieci i zapewnić bezpieczeństwo w internecie na różnych poziomach. Dzięki tym narzędziom rodzice mogą:

$\rightarrow$ wybrać gry, z których dzieci mogą korzystać (na podstawie klasyfikacji wiekowej PEGI);

$\rightarrow$ kontrolować i monitorować zakupy w internecie;

$\rightarrow$ ograniczyć dostęp do przeglądania internetu przez zastosowanie filtrów;

$\rightarrow$ kontrolować czas grania przez dzieci;

$\rightarrow$ kontrolować poziom interakcji online (czat) i wymiany danych (wiadomości tekstowe, treści generowane przez użytkowników).

\section{Amazon}

Po aktywowaniu kontroli rodzicielskiej dotyczącej zakupów w ramach aplikacji należy wprowadzić hasło do konta lub określony kod PIN, aby dokonać zakupu w sklepie Amazon Appstore na danym urządzeniu: amzn.to/2Ey05Fw.

\section{Apple iTunes Store}

Włączając ograniczenia na urządzeniu, można ustalić hasło, aby zapobiec dokonywaniu określonych rodzajów zakupów lub całkowicie wyłączyć możliwość kupna: apple.co/2GYwljj.

\section{Google Play}

Konfigurowanie ochrony za pomocą hasła w sklepie Google Play Store zapobiega dokonywaniu przypadkowych lub niechcianych zakupów za pośrednictwem urządzeń przenośnych lub telewizorów z systemem Android: support.google.com/googleplay/answer/1626831/?hl=en-GB.

\section{Microsoft}

Tworząc oddzielne konta dla wielu użytkowników, rodzice mogą zapobiec nieautoryzowanym zakupom przez konsolę Xbox One. Przy zakładaniu hasła trzeba się upewnić, że postronne osoby nie mogą zalogo- 
wać się na dane konto, dokonywać zakupów lub zmieniać ustawienia: bit.ly/1CaEKgL.

\section{Nintendo}

Na urządzeniach Nintendo Switch, Wii U, Nintendo 3DS lub Nintendo 2DS rodzice mogą ograniczyć korzystanie z kart kredytowych i zakupów online za pośrednictwem Nintendo Shopping Services. Wymaga to podania kodu PIN w celu doładowania środków za pomocą karty kredytowej lub dokonania zakupu.

\section{Sony}

Aby się upewnić, że dziecko nie dokona nieautoryzowanych zakupów na urządzeniach podłączonych do sieci PlayStation, rodzice powinni:

$\rightarrow$ ustalić hasło chroniące konto główne, aby zapobiec nieautoryzowanemu dostępowi ich dziecka, i aktywować ustawienie "hasło wymagane do zakupu", aby uniemożliwić kupno także na zalogowanym koncie;

$\rightarrow$ utworzyć subkonto dla każdego dziecka i ustawić kontrolę rodzicielską w celu ograniczenia lub uniemożliwienia jakichkolwiek zakupów na koncie rodzica: bit.ly/2sqUYkd.

\section{Zarządzanie grami za pomocą mediacji rodzicielskiej}

Technologia może pozytywnie oddziaływać na dzieci dzięki narzędziom, które pomagają im się uczyć w zabawny i angażujący sposób, wyrażać kreatywność i kontaktować się z innymi. W związku z tym, że młodzi ludzi są technologicznie zaawansowani, będą dobrze przygotowani do pracy, która w coraz większym zakresie będzie polegać na technologiach cyfrowych. Jednocześnie rodzice martwią się o to, że ich dzieci mogą mieć dostęp do nieodpowiednich treści online, że zbyt długi czasu spędzany przed urządzeniem cyfrowym wpłynie na ich zdrowie i rozwój, a także o to, że ich dzieci uzależniają się od technologii.

Umiejętność korzystania z mediów wiąże się z dokonywaniem selekcji, oceny i wykorzystaniem treści z korzyścią dla użytkownika. Podobnie jak w większości sytuacji, najlepiej sprawdza się zrównoważone podejście do nowych wyzwań. Ustawienie limitów czasu poświęconego na granie będzie pomocne w osiągnięciu równowagi między okresem spędzanym przed ekranem i poza nim. 
Wszyscy użytkownicy mediów, w tym dzieci i młodzież, samodzielnie decydują o sposobie spędzania wolnego czasu. Dostępnych jest tak wiele gier i innego rodzaju rozrywek cyfrowych, że każdy musi dokonywać wyborów w zakresie muzyki, której słucha, telewizji i filmów, które ogląda, oraz gier, z których korzysta. Na wybory te w dużym stopniu mają wpływ przyjaciele i koledzy (presja rówieśnicza). Ponadto każdy wybiera muzykę, gry i filmy, które sprawiają mu największą satysfakcję. Teoria użytkowania i gratyfikacji stanowi, że jednostki korzystają z mediów w celu zaspokojenia swoich potrzeb i pogłębienia zainteresowań. Badania sugerują, że ludzie wybierają zarówno tradycyjne, jak i nowe media, aby zaspokoić co najmniej pięć ogólnych potrzeb, jakimi są: rozrywka, poszukiwanie informacji, interakcja społeczna, spełnienie emocjonalne i odpowiedni poziom emocji („poszukiwanie wrażeń”), a także zabijanie czasu (Broekman i in. 2016). Na przykład niektóre gry toczą się w niezwykle szybkim tempie, zawierają dużą ilość akcji i głośną muzykę, co wywołuje silne emocje u osób, które ich szukają. Nie każdy jednak potrzebuje tego rodzaju bodźców, w związku z czym będzie unikał tego rodzaju aplikacji.

Mediacja rodzicielska to strategia stosowana w celu kontrolowania, nadzorowania lub objaśniania treści medialnych przeznaczonych dla dzieci. Zaangażowanie rodziców ma kluczowe znaczenie w procesie rozwijania u dzieci umiejętności korzystania z mediów i ich rozumienia, wspierania pozytywnych rezultatów i zapobiegania negatywnym skutkom dostępu do mediów. Rodzice są wzorem do naśladowania, a ich podejście do technologii wpływa na sposób, w jaki ich dzieci korzystają z tego rodzaju narzędzi.

Rodzice stosują jeden lub więcej z stylów mediacji w odniesieniu do gier i innych mediów:

1. Mediacja ograniczająca czas korzystania z gier i dostęp do niektórych treści.

2. Aktywna mediacja - omawianie treści i udzielanie dziecku wyjaśnień lub instrukcji w celu zwiększenia bezpieczeństwa, podniesienia świadomości krytycznej lub stymulowania efektów uczenia się.

3. Wspólne korzystanie z mediów przez rodziców i dzieci, głównie w celach rozrywkowych lub edukacyjnych.

4. Nadzór jako forma mediacji - pozostawanie w pobliżu w celu monitorowania dziecka, gdy korzysta ono z urządzeń elek- 
tronicznych lub monitorowanie aktywności dziecka w sieci, na przykład sprawdzanie historii przeglądarki lub logów z mediów społecznościowych.

5. Współczesne urządzenia elektroniczne umożliwiają rodzicom korzystanie z zabezpieczeń technicznych, czyli kontroli rodzicielskiej zapewnianej przez urządzenia multimedialne w celu stosowania ograniczeń lub blokowania nieodpowiednich treści (Nikken, Schols 2015).

Rodzice różnicują strategie mediacji w zależności od własnych poglądów na temat wpływu treści medialnych na odbiorców. Osoby, które są świadome ryzyka i zagrożeń, częściej starają się chronić swoje dzieci i dlatego monitorują, stosują ograniczenia w korzystaniu z mediów i wprowadzają nadzór. Z kolei rodzice, którzy uważają, że media to dobre narzędzia edukacji lub rozrywki, częściej wspólnie korzystają z mediów z dziećmi lub rozmawiają z nimi o zawartych w nich treściach. Wyniki jednego z badań pokazują, że rodzice częściej wspólnie grali ze swoimi dziećmi ( $w$ wieku 8-18 lat), gdy się spodziewali, że przyniesie to pozytywne skutki społeczno-emocjonalne (Nikken, Jansz 2006). Ograniczenie dostępu może przynieść skutki odwrotne do zamierzonych - "zakazany owoc" może stać się bardziej atrakcyjny.

Rodzice powinni rozmawiać ze swoimi dziećmi na temat tego, w co, kiedy i gdzie można grać. „Pierwszym krokiem jest zmiana często zadawanego pytania z «Jak chronić dziecko przed grami zawierającymi przemoc?» na «Jak pomóc dziecku w jak najlepszy sposób wykorzystać czas poświęcony na gry wideo?» [...] Ważna jest praca z dzieckiem i przekierowanie jego umiejętności i zainteresowań. [...] Nieporadność rodziców w grach wideo oraz brak wiedzy na ich temat mogą być wykorzystane do wzmocnienia relacji z dziećmi. W takiej sytuacji dochodzi do odwrócenia ról i dziecko staje się nauczycielem dla rodzica, a nie odwrotnie" (Kutner, Olson 2008, s. 220-221).

Warto pozwolić dzieciom opisać gry, z jakich korzystają, i omówić z nimi własne obawy dotyczące treści lub ograniczeń czasowych, na przykład kwestię dotyczącą umieszczenia komputera lub konsoli do gier w ich pokojach. Wyniki jednego z badań pokazują, że dzieci, które miały te urządzenia w swoim pokoju, ponaddwukrotnie częściej niż inne spędzały ponad 15 godzin tygodniowo na graniu (Kutner, Olson 2008). 
Aby wyznaczyć granice, w rozmowie warto wspomnieć o narzędziach kontroli rodzicielskiej.

Nastolatki rzadziej będą narzekać na ograniczenia, jeśli będą mieć udział w wyznaczaniu limitów. Jedno z badań wykazało, że to, jak tworzone są zasady, jest ważniejsze od samego ograniczania czasu poświęcanego na gry (Przybylski, Weinstein 2017). Najskuteczniejszym stylem mediacji jest ten, który uwzględnia autonomię dziecka i aktywną rolę dziecka w procesie podejmowania decyzji dotyczącej wprowadzenia zasad i ograniczeń (Fikkers, Piotrowski, Valkenburg 2017).

\section{Porady dla rodziców}

1. Zawsze sprawdzaj klasyfikację wiekową na opakowaniu gry lub w sklepie internetowym.

2. Zapoznaj się z opisem lub recenzją gry.

3. Monitoruj aktywność dzieci na stronach internetowych poświęconych grom lub - co jest bardziej efektywne - graj razem z nimi. Rozmawiaj na temat gier, wyjaśnij, dlaczego niektóre aplikacje mogą być nieodpowiednie. Można przy tej okazji także omówić to, w jaki sposób przekaz marketingowy wpływa na ludzi, oraz zachęcić dziecko do weryfikacji informacji i sceptycznego nastawienia do treści w internecie.

4. Uzgodnij wspólnie z dzieckiem ilość czasu, jaką może ono poświęcić na granie w tygodniu, każdego wieczora i w weekendy. Zachęcaj dziecko do robienia regularnych przerw w korzystaniu z urządzeń elektronicznych. Ustal pory, w jakich nie powinno się ich używać, na przykład podczas kolacji lub jazdy samochodem.

5. Pamiętaj, że gry mogą umożliwiać zakup dodatkowych treści.

6. Gry online są rozgrywane w wirtualnych społecznościach, które umożliwiają interakcję z nieznanymi osobami. Poinformuj dziecko, że nie wolno podawać swoich danych osobowych i że należy informować o niewłaściwych zachowaniach, takich jak zastraszanie, grożenie lub posługiwanie się wulgaryzmami, wyświetlanie niechcianych treści albo zaproszenia na spotkania poza grą. Zgłaszaj podejrzane aktywności, korzystając ze strony do przekazywania informacji zwrotnych lub ze specjalnych mechanizmów do składania skarg, dostępnych na konsolach albo stronach internetowych z grami. 
7. Za pomocą narzędzi kontroli rodzicielskiej ustaw limity (wieku, czasu, wydatków, dostępu online).

8. Podobnie jak sportowe gry wideo nie są tożsame $z$ aktywnością sportową, przyjaźnie online nie są wystarczającym substytutem relacji w świecie rzeczywistym. Młodzi ludzie powinni zachować równowagę między aktywnością w internecie i w świecie rzeczywistym, aby w pełni skorzystać z możliwości, jakie oferuje każdy z tych światów. Gry wideo powinny być częścią zróżnicowanej aktywności fizycznej i społecznej. Dla większości ludzi są one przez większość czasu bezpiecznym i satysfakcjonującym hobby.

Gry niosą ze sobą wiele potencjalnych korzyści, pod warunkiem, że są starannie dobrane (nawet te z gatunku akcji mogą mieć pozytywne oddziaływanie). Nieodpowiednie gry to takie, które mają klasyfikację wyższą niż wiek dziecka, są zbyt trudne lub ich treść może być niewłaściwa dla młodego użytkownika. Jeżeli stosujemy określone środki ostrożności, zachowujemy zdrowy rozsądek, zwracamy uwagę na klasyfikację, angażujemy się w gry razem z dziećmi oraz ustawiamy pożądane filtry i ograniczenia w urządzeniach, nie ma powodu, dla którego cała rodzina nie może cieszyć się bezpiecznym graniem.

Należy pamiętać, że gry wideo, niezależnie od tego, gdzie i jak się z nich korzysta, są formą rozrywki zapewniającej przyjemność i korzyści. Podobnie jak inne formy zabawy, pozwalają one graczom oderwać się od codzienności i zanurzyć się w świecie fantazji. Podczas zabawy można doskonalić również szeroki wachlarz umiejętności społecznych, komunikacyjnych, poznawczych, emocjonalnych i fizycznych.

\section{Więcej informacji:}

Adam Eichenbaum, Daphne Bavelier, C. Shawn Green (2015), Video games. Play that can do serious good, "American Journal of Play", 7(1), s. 50-74.

Autorzy dokonali przeglądu najnowszych badań, które pokazują, w jaki sposób współczesne gry wideo uwzględniają „wiele zasad, jakie psycholodzy, neurobiolodzy i pedagodzy uważają za kluczowe dla uczenia się". Udowodnili, że niektóre rodzaje gier komercyjnych wpływają na rozwój podstawowych umiejętności percepcyjnych i poznawczych. Opisali wykorzystanie gier wideo w różnych dziedzinach życia. 
Isabela Granic, Adam Lobel, Rutger C.M.E. Engels (2014), The benefits of playing video games, „American Psychologist”, 69, s. 66-78.

Zdecydowana większość badań dotyczących wpływu gier, przeprowadzonych przez psychologów, koncentruje się na ich negatywnym oddziaływaniu i potencjalnych zagrożeniach związanych z przemocą, uzależnieniami i depresją. Autorzy twierdzą, że potrzebne jest bardziej zrównoważone podejście, uwzględniające nie tylko możliwe negatywne skutki, ale także korzyści płynące z grania. Uwzględnienie potencjalnych pozytywnych aspektów jest ważne, ponieważ gry stają się coraz bardziej złożone, zróżnicowane, realistyczne i prospołeczne. W artykule autorzy podsumowują badania nad pozytywnymi skutkami gier wideo.

Lawrence Kutner, Cheryl K. Olson (2008), Grand Theft Childhood: The Surprising Truth about Violent Video Games and What Parents Can Do, New York: Simon \& Schuster.

Wnikliwa i dobrze napisana analiza dwóch kontrowersyjnych kwestii związanych z grami wideo: uzależnienia oraz przemoc i agresja. Książka zawiera również wyniki badań autorów prowadzonych z trudną młodzieżą, graczami i ich rodzicami.

Pamela M. Kato (2010), Videogames in health care: Closing the gap, „Review of General Psychology”, 14(2), s. 113-121.

Istnieje wiele przykładów innowacyjnego wykorzystania gier komercyjnych w służbie zdrowia lub do szkolenia przyszłych chirurgów. Aplikacje te, dostosowane do indywidualnych potrzeb, ułatwiają pacjentom przestrzeganie zaleceń medycznych, a lekarzom - trenowanie umiejętności przydatnych w różnych sytuacjach klinicznych. W artykule przedstawiono naukowe przykłady wykorzystania komercyjnych i specjalnie przygotowanych gier w szkoleniu personelu medycznego. 